DOI: $10.19195 / 0137-1134.119 .1$

\author{
JOANNA JUCHNIEWICZ \\ ORCID: 0000-0002-7837-0963 \\ Uniwersytet Warmińsko-Mazurski w Olsztynie
}

\title{
NAJWYŻSZA RADA WYMIARU SPRAWIEDLIWOŚCI KRÓLESTWA BELGII
}

\begin{abstract}
Abstrakt: Najwyższa Rada Wymiaru Sprawiedliwości Królestwa Belgii jest konstytucyjnym organem, niezależnym od władzy ustawodawczej, wykonawczej, sądowniczej. Działalność rozpoczęła w 2000 roku, a do jej zadań należy między innymi określanie warunków kształcenia sędziów i prokuratorów, występowanie z wnioskami o powołanie sędziów, opiniowanie projektów ustawodawczych, przeprowadzanie kontroli w obszarze sądownictwa, rozpatrywanie skarg indywidualnych na działalność organów sądowych. Skład Najwyższej Rady Wymiaru Sprawiedliwości odzwierciedla wielonarodową strukturę państwa, każda wspólnota ma w niej równą reprezentację. Członkami Rady są sędziowie, prokuratorzy oraz osoby reprezentujące belgijskie społeczeństwo.
\end{abstract}

Słowa kluczowe: Belgia, rada sądownictwa, władza sądownicza, niezależność, konstytucyjny organ

Królestwo Belgii jest niewielkich rozmiarów państwem położonym w północno-zachodniej części Europy, o strukturze federacyjnej ${ }^{1}$, opierającej się na podziale na trzy regiony: flamandzki, waloński oraz stołeczny region Brukseli. Składają się na nie trzy wspólnoty: flamandzka, walońska oraz niemieckojęzyczna. Jego ustrojem jest monarchia konstytucyjna, oparta na jednej z najdłużej obowiązujących na kontynencie europejskim konstytucji, uchwalonej w 1931 roku$^{2}$.

W swoim pierwotnym brzmieniu z 1931 roku Konstytucja nie przewidywała powołania specjalnego organu, którego zadaniem byłoby czuwanie nad niezależnością sądownictwa, ale też kontrolującego sądownictwo. Najwyższa Rada Wymiaru Sprawiedliwości (Hoge Raad de Justice, Conseil Superieur de la Justice) została

${ }^{1}$ Belgia nie od zawsze miała strukturę federalną. Napięcia między ludnością walońską a flamandzką doprowadziły do rozpoczęcia w latach siedemdziesiątych XX wieku procesu przekształcania państwa belgijskiego z unitarnego w federacyjne. Proces ten zakończył się w 1993 roku zmianą Konstytucji. Od tego momentu Królestwo Belgii jest federacją; zob. Konstytucja Królestwa Belgii, przeł., wstęp W. Skrzydło, Warszawa 2010, s. 13; M. Krzemiński, Królestwo Belgii, [w:] Ustrój Unii Europejskiej i ustroje państw członkowskich, red. P. Sarnecki, Warszawa 2007, s. 78.

2 Tekst Konstytucji Królestwa Belgii za: Konstytucja Królestwa Belgii... 
powołana w nowelizacji belgijskiej ustawy zasadniczej z 20 listopada $1998 \mathrm{roku}^{3}$. Impulsem do jej utworzenia była tak zwana afera Marca Dutroux, a także „Biały marsz", zorganizowany 20 października 1996 roku jako protest przeciwko pedofilii. Jednak potrzeba i plany utworzenia Rady były sygnalizowane znacznie wcześniej, a u ich podłoża legł spadek zaufania obywateli do policji i organów sądowych ${ }^{4}$. Budowanie zaufania do sądownictwa było znaczącym elementem w pracach nad utworzeniem rady, dlatego chcąc doprowadzić do jego wzrostu i umocnienia, twórcy rozwiązań nie ograniczyli się do utworzenia organu reprezentującego jedynie sędziów, ale zapewnili w nich szeroką reprezentację przedstawicieli belgijskiego społeczeństwa.

Konstytucyjne podstawy działalności Rady zostały zawarte w art. 151 Konstytucji, status zaś jej członków, mechanizmy ich wyboru, organizacja i kompetencje w art. 259 bis belgijskiego kodeksu sądowego ${ }^{5}$. Najwyższa Rada Wymiaru Sprawiedliwości (dalej: Rada) jest konstytucyjnym organem, niezależnym od władzy wykonawczej, administracji oraz, mimo umieszczenia artykułu jej poświęconego w rozdziale szóstym „O władzy sądowniczej”, niezależnym od sądownictwa. W ustawie zasadniczej podkreślono niezależność Rady, ale jednocześnie zobowiązano ją do szanowania zasad niezależności obejmujących niezawisłość sędziów w zakresie orzekania i niezależność prokuratury w prowadzeniu śledztw i ścigania. W jej działalności można wyróżnić trzy główne obszary ${ }^{6}$. Pierwszy wiąże się z karierą sędziowską i obejmuje przeprowadzanie egzaminów otwierających dostęp do urzędu sędziego i prokuratora, przedstawianie wniosków o powołanie na stanowisko sędziego ${ }^{7}$ i na kierownicze stanowiska w prokuraturze oraz kształcenie sędziów. Druga grupa to uprawnienia opiniodawcze, obejmujące wydawanie opinii i propozycji dotyczących funkcjonowania i organizacji sądownictwa, a także podejmowanie inicjatyw prawodawczych. Izba Reprezentantów, Senat oraz Minister Sprawiedliwości mogą zwracać się do Rady o przedstawienie opinii na temat przygotowywanych inicjatyw ustawodawczych, aczkolwiek ma ona prawo do opiniowania wszelkich aktów mogących wpływać na działalność sądownictwa. Rada jest wyposażona także w kompetencje do kontrolowania i nadzorowania działalności wymiaru sprawiedliwości (przeprowadzanie audytów, dochodzeń, wydawanie zaleceń, rozpatrywanie skarg na funkcjonowanie sądownictwa). In-

3 Swoją działalność Rada rozpoczęła w 2000 roku.

${ }^{4}$ http://www.hrj.be/nl/inhoud/geschiedenis (dostęp: 21.08.2018). Zob. także https://iws.gov.pl/ wp-content/uploads/2019/05/IWS-Pog\%C5\%82\%C3\%B3dek-A.-red._Rady-S\%C4\%85downictwa-w-pa $\%$ C5\%84stwach-Unii-Europejskiej.-Przegl $\%$ C4\%85d-rozwi $\%$ C4\%85za\% $\%$ C5\%84.pdf(dostęp: 30.09.2019).

5 Gerechtelijk Wetboek z dnia 10 października 1967 roku, http://www.ejustice.just.fgov.be/ cgi_loi/change_lg.pl?language $=$ fr\&la=F\&table_name=loi\&cn=1967101002 (dostęp: 23.08.2018), dalej: k.s.

${ }^{6}$ Zob. także https://e-justice.europa.eu/content_legal_professions-29-be-pl.do?init=true\& member=1 (dostęp: 23.08.2018).

${ }^{7}$ W Belgii sędziowie powoływani są przez króla. 
strumenty w dyspozycji Rady pozwalają jej samodzielnie prowadzić kontrole, może ona dokonywać analiz i oceny stosowania wewnętrznych mechanizmów i procedur kontroli. Ma też prawo informowania organów dyscyplinarnych o dostrzeżonych uchybieniach czy nieprawidłowościach w działaniu sędziów i wnioskowania o zbadanie przez nie, czy zachodzą przesłanki skutkujące możliwością egzekwowania odpowiedzialności dyscyplinarnej.

W skład Rady wchodzi 44 członków. Ze względu na jej mieszany charakter są to nie tylko sędziowie, lecz także osoby zajmujące się innymi profesjami prawniczymi i przedstawiciele tak zwanego społeczeństwa obywatelskiego, co ma gwarantować szeroką reprezentację społeczną. Charakterystycznym rozwiązaniem, wynikającym ze struktury narodowościowej Królestwa Belgii i oparcia funkcjonowania państwa na wspólnotach narodowych, jest podwójna reprezentacja osób zasiadających w Radzie. Wyraża się to koniecznością reprezentacji określonych grup zawodowych (sędziowie i prokuratorzy) oraz osób, które nie są sędziami. Równolegle muszą znaleźć się w niej również przedstawiciele dwu grup językowych. Ta dwoistość struktury uwidacznia się nie tylko w składzie Rady, ale ma zasadniczy wpływ na skład i działalność wszystkich organów Najwyższej Rady Sprawiedliwości.

W działalności Rady główną rolę odgrywają dwa kolegia: niderlandzko- i francuskojęzyczne. Każde z nich liczy 22 członków — w równej liczbie 11 miejsc dzieli się między sędziów, prokuratorów (pierwsza grupa) i osoby niebędące sędziami. W grupie 11 „niesędziów” musi być czterech prawników z co najmniej dziesięcioletnim stażem, trzech profesorów uniwersytetu lub wyższej szkoły we Wspólnocie Flamandzkiej lub Francuskiej z odpowiednim doświadczeniem zawodowym oraz cztery osoby mające co najmniej dyplom ukończenia kolegium flamandzkiego lub francuskiego i co najmniej dziesięcioletnie doświadczenie zawodowe w dziedzinie prawnej, gospodarczej, społecznej, administracyjnej lub naukowej. Przepisy określające skład Rady wymagają także, aby przynajmniej jeden z członków francuskojęzycznych wykazywał się kompetencją w zakresie znajomości języka niemieckiego. Wszyscy członkowie Rady muszą korzystać z pełni praw obywatelskich i politycznych, nie mogą być karani, ponadto w stosunku do niebędących sędziami wprowadzono parytet płci — w grupie tej musi znaleźć się co najmniej czterech członków każdej płci (art. 259bis1 § 3 k.s.).

Procedura wyboru członków Rady jest rozbudowana i przebiega dwutorowo, odmiennie dla sędziów, prokuratorów i odmiennie dla osób nimi niebędących ${ }^{8}$. Sędziowie wybierani są spośród czynnych sędziów i prokuratorów przez kolegium elektorów. Co istotne, głosowanie ma charakter obowiązkowy i tajny, a każdy wyborca dysponuje trzema głosami: na sędziego, na prokuratora i na kandydata każdej płci. Następnie ustalana jest lista kandydatów według liczby uzyskanych głosów i ci, którzy otrzymali ich najwięcej, uzyskują mandat członka Rady. Jeśli

${ }^{8}$ Przebieg procedury wyboru członków Najwyższej Rady Sprawiedliwości określa art. 259bis2 k.s. 
kilku kandydatów uzyska równą liczbę głosów, mandat przypadnie temu, kto ma dłuższy staż pracy, a gdyby i w ten sposób nie można było ustalić, który kandydat powinien zasiadać w Radzie, decyduje wiek kandydata ${ }^{9}$.

Członkowie Rady niebędący sędziami wybierani są przez organ władzy ustawodawczej - Senat ${ }^{10}$ - większością 2/3 głosów. Kandydaci mogą zgłaszać się sami osobiście, kandydatury mogą zgłaszać także stowarzyszenia adwokackie, uniwersytety oraz kolegia wspólnot francusko- i niderlandzkojęzycznej. Poza koniecznością spełnienia przesłanek materialnych związanych z wykształceniem czy stażem pracy w stosunku do kandydatów wprowadzono ograniczenie wiekowe. W chwili składania wniosku kandydat nie może mieć ukończonych 66 lat.

Kadencja członków Rady wynosi cztery lata, a mandat członka można pełnić przez maksymalnie dwie kadencje. Wszyscy członkowie Najwyższej Rady Sprawiedliwości są niezależni, na ich działania nie mogą wpływać jakiekolwiek organy zewnętrzne, a w swojej działalności zobowiązani są do przestrzegania zasad etyki. Wygaśnięcie mandatu przed upływem kadencji następuje w wypadku jego zrzeczenia się, utraty zdolności zasiadania w Radzie oraz w przypadku wyboru na stanowisko, którego nie można łączyć ze stanowiskiem członka Rady (na przykład wyboru na urząd o charakterze publicznym). $Z$ ważnych powodów członek może zostać odwołany przez Radę większością $2 / 3$ głosów. W razie wygaśnięcia mandatu przed upływem czteroletniej kadencji nie przeprowadza się wyborów uzupełniających, a opróżnione miejsce zajmują osoby, które uczestniczyły w procedurze wyboru. Po każdych wyborach tworzona jest bowiem lista zastępczych sędziów (według liczby uzyskanych głosów) oraz lista niewybranych osób niebędących sędziami i spośród nich wyłaniane są te obejmujące wakujący mandat.

Najwyższa Rada Wymiaru Sprawiedliwości jest ciałem o stosunkowo rozbudowanej strukturze. Organizacja wewnętrzna opiera się na czterech organach: Zgromadzeniu Ogólnym, Biurze, kolegiach językowych oraz komisjach. Charakterystyczne dla belgijskiego modelu jest kształtowanie składu organów wewnętrznych na podstawie zasady równego podziału miejsc między wspólnoty językowe oraz równego podziału miejsc między reprezentantów sędziów i prokuratorów oraz reprezentantów społeczeństwa.

Zgromadzenie Ogólne skupia wszystkich 44 członków Rady. Do jego podstawowych zadań należy zatwierdzanie opinii, wniosków, sprawozdań, decyzji, programów i innych aktów przedstawianych przez komisje oraz kolegia. Podejmuje ono decyzje o zakończeniu kadencji członka Rady oraz dokonuje wyboru Biura, a także opracowuje i przedstawia każdego roku sprawozdania dotyczącego funk-

${ }^{9}$ Przepisy kodeksu sądowego przewidują również procedurę odwoławczą, z której może skorzystać każdy kandydat, który nie został wybrany; zob. art. 259bis $§ 4$ k.s.

${ }^{10}$ Co istotne dla zapewnienia reprezentatywności członków niemających statusu sędziego, struktura belgijskiego Senatu też zapewnia reprezentację wspólnot; zob. art. 67 i 68 Konstytucji Belgii. Więcej zob. także M. Krzemiński, op. cit., s. 81-81; A. Głowacki, System konstytucyjny Belgii, Warszawa 1997, s. 32-33. 
cjonowania sądownictwa Belgii. Sprawozdanie przedstawiane jest obu organom władzy ustawodawczej — Izbie Reprezentantów oraz Senatowi — ponadto Ministrowi Sprawiedliwości oraz osobom kierującym sądami i prokuraturą. Posiedzenia Zgromadzenia Ogólnego powinny odbywać się nie rzadziej niż raz w miesiącu. Tak jak odnośnie do pozostałych organów Rady Zgromadzenie rozpatruje sprawy objęte porządkiem obrad, co do zasady podejmując rozstrzygnięcia bezwzględną większością głosów.

Centralnym organem Rady jest Biuro liczące cztery osoby, wybierane przez Zgromadzenie Ogólne większością 2/3 głosów. Kodeks sądowy wymaga, aby zasiadało w nim dwóch sędziów i dwie osoby niebędące sędziami, wskazywanych przez każde kolegium językowe. W ten sposób zapewniona jest reprezentacja wspólnot francuskojęzycznej oraz niderlandzkojęzycznej. Osoby wchodzące w skład Biura, jako jedyni członkowie Rady, zatrudnione są w pełnym wymiarze czasu i z tego tytułu pobierają wynagrodzenie, nie mogąc równolegle podejmować innego zatrudnienia. W wyjątkowych przypadkach, o ile nie będzie to kolidowało z obowiązkami wynikającymi z pracy w Biurze, Najwyższa Rada Wymiaru Sprawiedliwości może odstąpić od tego zakazu, wyrażając zgodę na podjęcie innego jeszcze zatrudnienia. Na wniosek Rady monarcha może zwiększyć liczbę członków Biura, z zastrzeżeniem zachowania proporcji podziału miejsc, tak by każda z grup członków oraz każde kolegium językowe były reprezentowane na równych zasadach. Kolejnym rozwiązaniem korespondującym z zasadą równości jest reguła mówiąca o tym, że każdy z członków Biura przez rok przewodniczy Najwyższej Radzie Sprawiedliwości.

Do organów Rady należy zaliczyć kolegia językowe - francuskojęzyczne i niderlandzkojęzyczne, oba liczące 22 członków, składające się w równej części z sędziów i osób niebędących sędziami, a ponadto, o czym była mowa wcześniej, w grupie niesędziów powinny znaleźć się osoby według określonego parytetu. Kolegia językowe prowadzą działania w swoim języku, za tłumaczenia odpowiada Rada. Ich zadania koncentrują się na rozpatrywaniu konkretnych spraw związanych z nominacjami, skargami. Oba kolegia mogą odbywać wspólne posiedzenia.

W ramach każdego kolegium językowego powoływane są dwie komisje: nominacyjna oraz opiniodawczo-śledcza. Ich przewodniczącymi mogą być tylko członkowie Biura, natomiast w razie nieobecności na konkretnym posiedzeniu komisji zastępowani są przez obecnego na posiedzeniu najstarszego jej członka.

Komisja nominacyjna liczy 14 członków. W równych częściach w jej skład wchodzą sędziowie i osoby niebędące sędziami. W komisji nominacyjnej działającej w ramach kolegium francuskojęzycznego przynajmniej jeden członek komisji musi znać język niemiecki. Komisje obradują na posiedzeniach, do ważności podejmowanych decyzji wymagane jest kworum liczące minimum 10 członków. Komisje nominacyjne obu kolegiów mogą tworzyć wspólną komisję, której zadaniem jest przygotowywanie programu badania kompetencji zawodowych, przygotowywanie egzaminów zawodowych. Właściwość komisji nominacyjnych obejmuje 
zgłaszanie kandydatów mających uzyskać mianowanie na stanowisko sędziego, organizowanie egzaminów zawodowych i egzaminów wstępnych do szkolenia sędziów. Każda komisja jest zobligowana do przedstawiania Zgromadzeniu Ogólnemu rocznego sprawozdania ze swojej działalności.

Drugim rodzajem komisji tworzonych w ramach każdego kolegium językowego są komisje opiniodawczo-śledcze. Są one mniej liczne, w ich skład wchodzi bowiem ośmiu członków, lecz także w równej liczbie muszą rekrutować się z grona sędziów i osób niebędących sędziami. Jak w komisjach nominacyjnych, tak i tu przewodniczenie obu komisjom przypisane zostało członkom Biura. Do zadań komisji należy przygotowywanie z własnej inicjatywy lub na wniosek Zgromadzenia Ogólnego, Ministra Sprawiedliwości, większości członków Izby Reprezentantów lub Senatu opinii i propozycji dotyczących funkcjonowania sądownictwa, przygotowywanie wniosków i projektów ustaw, które mogą mieć wpływ na funkcjonowanie wymiaru sprawiedliwości, opinii na temat sposobu wykorzystania dostępnych środków budżetowych. Opinie wymagają zatwierdzenia przez Zgromadzenie Ogólne. Wyjątkiem jest uznanie przez organ występujący o przedstawienie opinii, którym może być Minister Sprawiedliwości, większość deputowanych Izby Reprezentantów lub Senatu, że opinia powinna zostać sporządzona w trybie pilnym.

Komisje opiniodawczo-śledcze są właściwe również do rozpatrywania i monitorowania skarg dotyczących funkcjonowania sądownictwa ${ }^{11}$. Kodeks sądowniczy określa szeroki katalog wyłączeń w odniesieniu do kompetencji badania skarg przez komisje. Mianowicie, komisje nie mogą badać skarg, jeżeli wymagałoby to podjęcia działań karnych i dyscyplinarnych przysługujących innym organom, skarg dotyczących treści orzeczenia sądowego, skarg, których rozstrzygnięcie można osiągnąć, stosując zwyczajne, ewentualnie nadzwyczajne środki, skarg dotyczących rozpatrzonych spraw, jeżeli nie wskazano żadnej nowej okoliczności, skarg dotyczących spraw pozostających w toku oraz skarg oczywiście bezzasadnych.

Komisje opiniodawczo-śledcze obu kolegiów językowych mogą tworzyć wspólną komisję. Jej zadaniem jest monitorowanie stosowania mechanizmów kontroli w sądownictwie. Komisja może zwracać się do innych organów o przekazanie informacji potrzebnych do realizacji wskazanego zadania. Wspólna komisja zobligowana została do przedstawiania corocznie sprawozdania na temat sposobu prowadzenia kontroli wewnętrznych w sądownictwie oraz zgłaszania propozycji w przedmiocie poprawy efektywności prowadzonej kontroli. Zgodnie z art. 259 bis 16 k.s. wspólna komisja może przeprowadzić z inicjatywy własnej, na wniosek Ministra Sprawiedliwości, Izby Reprezentantów lub Senatu specjalne dochodzenie w sprawie funkcjonowania systemu sądownictwa, z zastrzeżeniem, że nie może ono wkraczać w sferę działań karnych i dyscyplinarnych. Dochodzenie prowadzone jest przez komendanta policji, w wyjątkowych wypadkach może

11 Skarga musi być złożona na piśmie, zawierać dokładne określenie przedmiotu zaskarżenia, a także imię i nazwisko, adres, podpis skarżącego oraz datę skierowania skargi. 
prowadzić je sama komisja, jeżeli z takim wnioskiem wystąpi Minister Sprawiedliwości, a także jeżeli ze względu na przedmiot sprawy nie jest zalecone przeprowadzenie postępowania dochodzeniowego przez komendanta policji.

Ważnym elementem funkcjonowania Rady jest prowadzenie oceny działania sądownictwa i formułowanie w tym przedmiocie na przykład zaleceń. Tytułem przykładu można wskazać zalecenie Rady z 14 czerwca 2018 roku (nr 2018/1) ${ }^{12}$. W związku ze złożoną skargą dotyczącą niezawiadomienia strony postępowania o przełożeniu posiedzenia sądu Rada zaapelowała do prezesów sądów, personelu urzędniczego, aby zwracali uwagę na odpowiednie informowanie stron postępowania o przełożonych posiedzeniach sądu, by w ten sposób gwarantować im dochodzenie sprawiedliwości.

W styczniu 2018 roku Rada opublikowała audyt na temat zarządzania personelem w sądach pierwszej instancji ${ }^{13}$, wskazując w sformułowanych wnioskach, że dotychczasowa praktyka określania potrzeb kadrowych nie była oparta na obiektywnej analizie, lecz w ramach określonych ram kadrowych, co w konsekwencji prowadziło do pogarszania efektywności prac sądów. W zaleceniach Rada wskazywała na konieczność opracowania strategicznej wizji zarządzania personelem w sądownictwie i przygotowania na podstawie strategii przez sądy polityki kadrowej. Uwagi Rady adresowane były również do Ministerstwa Sprawiedliwości i organów władzy ustawodawczej, by przez środki znajdujące się w ich dyspozycji, zarówno związane z zarządzaniem, jak i budżetowaniem organów ujętych w strukturze sądownictwa, włączyły się w prace mające na celu poprawę zarządzania personelem sądów.

Działająca od 2000 roku Najwyższa Rada Wymiaru Sprawiedliwości Królestwa Belgii jest konstytucyjnym organem, niezależnym od władzy ustawodawczej, wykonawczej, sądowniczej, do którego zadań należy między innymi określanie warunków kształcenia sędziów i prokuratorów, występowanie z wnioskami o powołanie sędziów, opiniowanie projektów ustawodawczych, przeprowadzanie kontroli w obszarze sądownictwa oraz rozpatrywanie skarg indywidualnych na działalność organów sądowych. Charakterystycznym dla Rady rozwiązaniem, wynikającym ze struktury narodowościowej państwa belgijskiego, jest ukształtowanie składu osobowego Rady w sposób, w którym każda ze wspólnot ma w niej równą reprezentację. To też rzutuje na skład organów wewnętrznych i prowadzenie spraw niejako w strukturach kolegiów francusko- i niderlandzkojęzycznego. Warto wskazać na mieszany, nie tylko w odniesieniu do wspólnot językowych, skład tego organu, lecz także udział w jej pracach osób, które nie zajmują stanowiska sędziego lub prokuratora, będących przedstawicielami tak zwanego społeczeństwa obywatelskie-

12 http://www.hrj.be/sites/default/files/press_publications/recommandation_definitif_bilingue.pdf (dostęp: 23.08.2018).

$13 \mathrm{http}: / /$ www.hrj.be/sites/default/files/press_publications/audit-personeelsbeheer-reas_nl-samenvatting.pdf (dostęp: 23.08.2018). 
go. Całokształt działań Rady, jak sama na swoich oficjalnych stronach podkreśla, skierowany jest na poprawę funkcjonowania sądownictwa w Królestwie Belgii.

\section{THE HIGH COUNCIL OF JUSTICE IN THE KINGDOM OF BELGIUM}

\section{Summary}

The High Council of Justice of the Kingdom of Belgium is a constitutional body, autonomous from the legislative, the executive, and the judiciary. The Council commenced its activities in 2000 and its tasks include setting the requirements for the training of judges and prosecutors, submitting motions for the appointment of judges, issuing opinions on draft acts, performing audits in the judiciary and processing individual complaints against the activities of judicial authorities. The composition of the High Council of Justice reflects the multinational structure of the state, each of the communities has equal representation in the Council. The members of the Council are selected from among judges, prosecutors and representatives of Belgian society.

Keywords: Belgium, Council of Justice, the judiciary, autonomy, constitutional body

\section{BIBLIOGRAFIA}

Głowacki A., System konstytucyjny Belgii, Warszawa 1997.

Konstytucja Królestwa Belgii, przeł., wstęp W. Skrzydło, Warszawa 2010.

Krzemiński M., Królestwo Belgii, [w:] Ustrój Unii Europejskiej i ustroje państw członkowskich, red. P. Sarnecki, Warszawa 2007.

\section{ŹRÓDŁA INTERNETOWE}

https://e-justice.europa.eu/content_legal_professions-29-be-pl.do?init=true\&member=1 (dostęp: 23.08.2018).

https://iws.gov.pl/wp-content/uploads/2019/05/IWS-Pog\%C5\%82\%C3\%B3dek-A.-red._Rady-S\%C4\%85downictwa-w-pa\%C5\%84stwach-Unii-Europejskiej.-Przegl $\%$ C4\%85d-rozwi\%C4 \%85za\%C5\%84.pdf (dostęp: 30.09.2019).

http://www.ejustice.just.fgov.be/cgi_loi/change_lg.pl?language $=$ fr\&la $=F \& t a b l e \_n a m e=l o i \& c n=$ 1967101002 (dostęp: 23.08.2018).

http://www.hrj.be/nl/inhoud/geschiedenis (dostęp: 21.08.2018).

http://www.hrj.be/sites/default/files/press_publications/audit-personeelsbeheer-reas_nl-samenvatting.pdf (dostęp: 23.08.2018).

http://www.hrj.be/sites/default/files/press_publications/recommandation_definitif_bilingue.pdf (dostęp: 23.08.2018). 